scourge. Surely then it is all to the good that a man should grant his fellows at least the benefits of his experience. This applies to medical officers of health, pathologists, university teachers and bacteriologists and of course to general practitioners.

So far as this journal is concerned, although it undertakes the publication of papers given at meetings of the Medical Society for the Study of Venereal Diseases, there is always space for articles by reliable authors. An article need not necessarily be fully written before it is submitted; all that is required is that the author should get in touch with the Editor and give him a few notes. The germs of the idea might then easily be fostered, for it should not be forgotten that an editorial staff exists for the purpose of giving all possible assistance to the author. Anyone engaged in medical journalism, however, will affirm that there is no penance more closely associated with the wearing of the hair shirt than that of trudging a weary way through pages of badly written and verbose manuscript, with facts unmarshalled and paragraphs in disorder ; the great art in any article lies in its presentation. Many a man fails too because he has never been taught properly the art of essay-writing.

To turn from what may be termed the philosophical aspect to the more practical side of authorship, it may be helpful to enumerate brief principles which would make for a better service of articles for this journal.

(1) Papers read before the Medical Society for the Study of Venereal Diseases should be revised for press. It is a well-known fact that papers prepared for delivery at a meeting do not look so well in print.

(2) Contributions should be typewritten on one side of the paper only, with double spacing and a wide margin at the left-hand side.

(3) The names of authors and, when appropriate, the department from which the work is produced should be indicated in the sub-title.

(4) Illustrations and tables should be on separate sheets. All illustrations should be supplied in a form suitable for photographic reproduction. Thus drawings should be large-scale in Indian ink on a smooth white surface. If rough drawings are sent they can easily be redrawn by the staff artist. Magnification of all photomicrographs should be indicated. The loan of any illustration should be acknowledged in the legend.

(5) Any author mentioned in a paper should be listed in the references at the end of the article.

If attention were paid to the above points it would make the work very much easier, but more than that it would ensure that the author's manuscript was likely to be accepted, because there can be no denying that a well set out contribution has a certain value in aesthetic appeal and commands the immediate attention and interest of the Editor.

\title{
Sulphonamides in general practice
}

Bradlow discusses the use and abuse of the sulphonamides in general practice and states that " every practitioner is aware of the patient with gonorrhoea who has treated himself with hopelessly inadequate doses of 'M. \& B.', and who by the time he comes to the doctor no longer responds to the proper use of the drug',' Both this statement and a reference to the continued pur'chase by patients of mixtures containing sulphonamide drugs, on a prescription once given, indicate easy access by the public in the Transvaal to these drugs. In general Bradlow considers the main errors of dosage to be : (1) too small a dosage, (2) too light an initial dose, (3) indiscriminate prescription for any kind of pyrexia, (4) inclusion of sulphonamide in a " blunderbuss ", prescription, (5) prolonged use without watching the patient's blood picture and (6) a too sudden withdrawal of the drug.-South African Medical Journal, 13th May 1944.

\section{Legal right to examine prostitutes for venereal diseases}

A statute in the State of Illinois provides that if any person coming before any judge or justice of the peace on any criminal charge is suspected of suffering from any communicable venereal disease, the judge or justice shall cause the defendant to be examined for the presence of venereal disease. If the person is found to be infected, he or she may be committed to an appropriate institution for segregation and treatment. The validity of the Illinois statute in relation to the constitution of the State and of the United States of America has been challenged by two women who were charged with solicitation to prostitution. They refused to submit to examination and filed petitions for writs of habeus corpus. The Supreme Court of Illinois upheld the action of the court which committed them for examination, on the ground that the statute did not violate the constitution because it was based on the police powers of the State and did not fall within the provisions of the criminal code.-Journal of the American Medical Association, June 1944. 